\title{
BIOSTRATIGRAPHY OF CRETACEOUS- TERTIARY BOUNDARY IN SOUTHWESTERN OF TRIPOLI/SABRATH BASIN OFFSHORE LIBYA (CONCESSION NC41)
}

\author{
Almagtof Ahmed Abuharbah ${ }^{1}$, Emhemed Alfandi $^{2}$, and Mohamed Ali Alrabib ${ }^{3}$ \\ ${ }^{1,3}$ Dept. of Geology-Faculty of Sciences-Zawia University \\ ${ }^{2}$ Dept. of Geology-Faculty of Sciences- Sabratha University
}

\begin{abstract}
The present study deals with Cretaceous- Tertiary unconformity in the southwestern part of the Tripoli- Sabratha Basin Off-Shore Libya (Concession 41). A detailed biostratigraphic study has mainly carried out by means of ditch cutting samples analysis from five wells: F1, N1, G1, P11and K1 NC41. Successive sediments above and below the Cretaceous / Tertiary boundary are related to the following formation: Metlaoui Formation, El Haria Formation (A\&B Members), Abiod Formation, Aleg Formation, Doulelb Equivelant Formation and Zebbag or Zebbag Eq. Formation, that have a wide distribution in both OffShore Libya and Tunisia Biostratigraphic analysis led to the identification of Upper and Lower Paleocene Bio-Zones, according to the biostratigraphic scheme proposed by Agip (1985) for the Mediterranean area.
\end{abstract}

In the study area the duration of the Cretaceous / Tertiary hiatus increases from east to west. The South- eastern side of NC41 (well F1) has a minimum hiatus of the Cretaceous/Tertiary unconformity. In the South-western side (Wells N1, G1, P1, \&K1) the Cretaceous/Tertiary unconformity increases to reach the maximum hiatus in Well P1 where the Conacian/Santonian sediments (Douleb Eq) are overlain by the Lower Eocene sediment (Metlaoui Formation). Absolute value of the Cretaceous / Tertiary hiatus can be estimated by absence of successive bio-zones. Consequently, minimum approximates to $2 \mathrm{MY}$ marked in Well F1, and maximum hiatus approximates to 30 MY marked in Well P1.

The occurrence and relative abundance of planktonic and several benthic foraminiferal taxa can be used to recognize the depositional environments. During most of the Upper Cretaceous and Lower Paleocene deep marine conditions prevailed. Conversely, the Lower Eocene was mainly characterized by shallow marine conditions.

Keywords: Cretaceous-Tertiary, Sabratha Basin, biostratigraphic.

\section{Introduction}

This study aims to investigate the Cretaceous- Tertiary unconformity in the southwestern part of Tripoli- Sabratha Basin Off-Shore Libya (Concession 41) in an attempt to outline the 
distribution of the planktonic foraminiferal zonation that represent Early Paleocene and Late Cretaceous Table (1).

Documentation and material used are mainly electric logs, stratigraphic reports and ditch samples of five wells located in the study area (F1, G1, N1, P1 and K1) Figure (1) according to well sampling intervals as follows:

F1 /NC41 from 10100' to 13393 (TD)

N1/NC41 from 9500 to 10356' (TD)

G1/NC41 from 9000' to $9555^{\prime}$ (TD)

P1/NC41 from 9216' to 9835' (TD)

K1/NC41 from 9824' to 10140 ' (TD)

A detailed microscopic analysis was carried out to investigate the planktonics zonal markers and their faunal assemblages of each well.

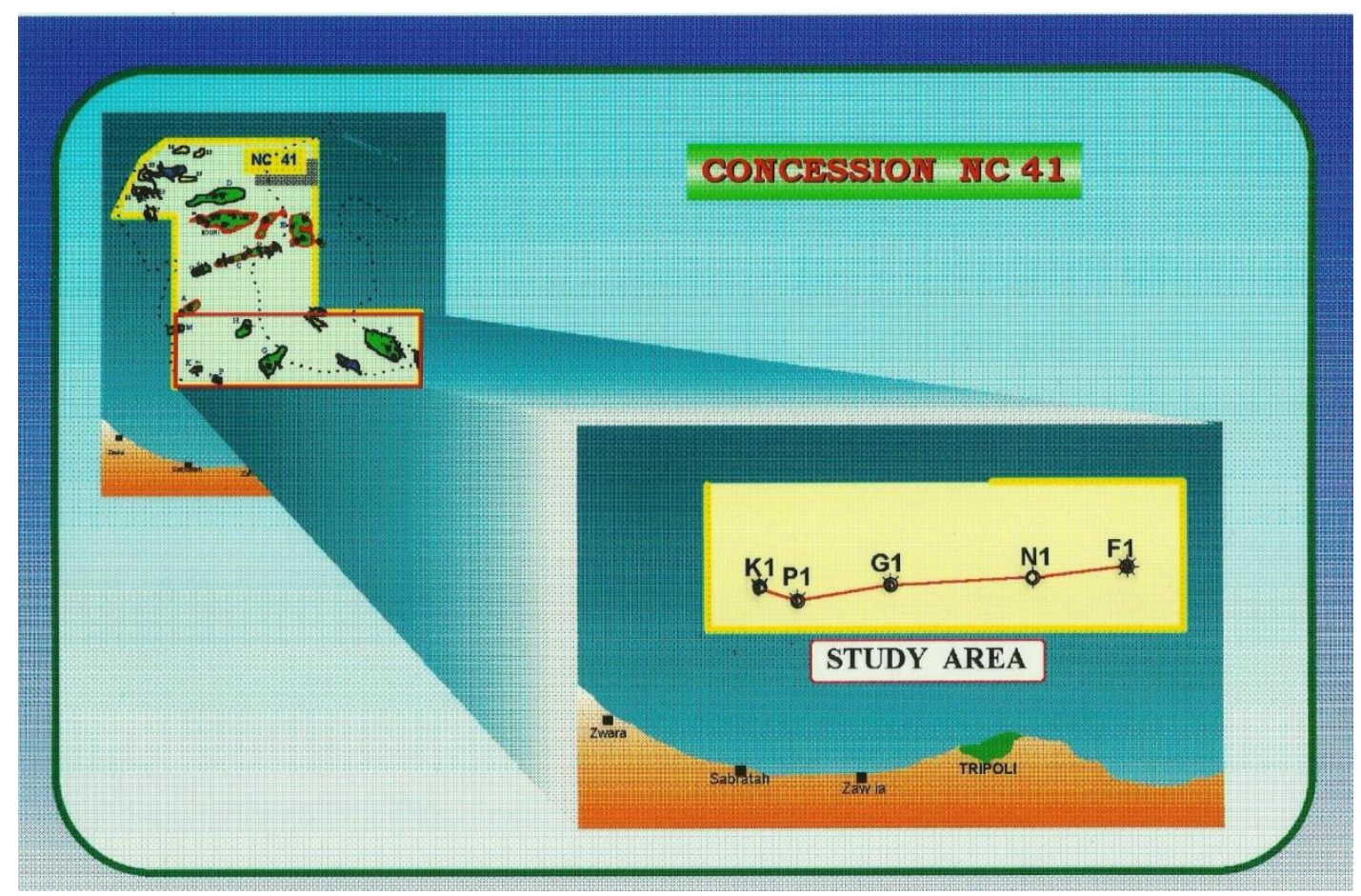

Figure (1): Location Map of The Study Area

Analysis of the foraminiferal assemblages above and below of the Cretaceous- Tertiary boundary sediments allowed us to determine the biozones immediately above and below this unconformable contact. 
The Cretaceous- Tertiary boundary is lying in the deep marine environment sediment "El Haria Fm." In the eastern part of the study area in F1/NC41 well. While in the rest of the study area (N1, G1, and K1 wells) it lies between shallow marine environment sediment of the Metlaoui Formation and deep marine environment sediment El Haria "A". Conversely, in P1/NC 41 well it lies between Metlaoui Formation and Douleb Formation shallow marine environments (annex 1) in which the maximum hiatus of the Cretaceous / Tertiary boundary is marked, whereas in F1 / NC41 well the minimum hiatus can be observed by the last occurrence of Globotrancana Contusa, first occurrence of small Globigerrinidae and Globotrancana daubjergensis from which about 2 M.Y. of missing time can be estimated (Douglas, 1972).

This lack of time increases towards the West of the study area, where it reaches its maximum of 30 M.Y. in P1 /NC41 well in which the whole Paleocene, Maastrichtian and Campanian time is missing, as indicated by the absence of 15 biostratigraphic subzones Table (2).

\section{Geological Setting}

Since the Triassic tectonic phase, the Libyan offshore and its surrounding areas seemed to be marked by a rigid block fault pattern, probably due to deep seating rifting affecting the substratum, with clear NW- SE trend (Jeffara fault system to the south and Isis Jerrafa ridgeKerkenneh uplift to the north Anketell and Ghellai.l 1991) Figure (2).

This rifting produced a symmetric basin and the tectonic elements have been rejuvenated during the middle Jurassic and Upper Cretaceous (Breschi \& Gaith.1989). These tectonic elements oriented NW - SE "Sirtic trend" intersected with WSW - ESE oriented "Salt" trend, which has affected the basin since Late Cretaceous (Lazzari, 1990).

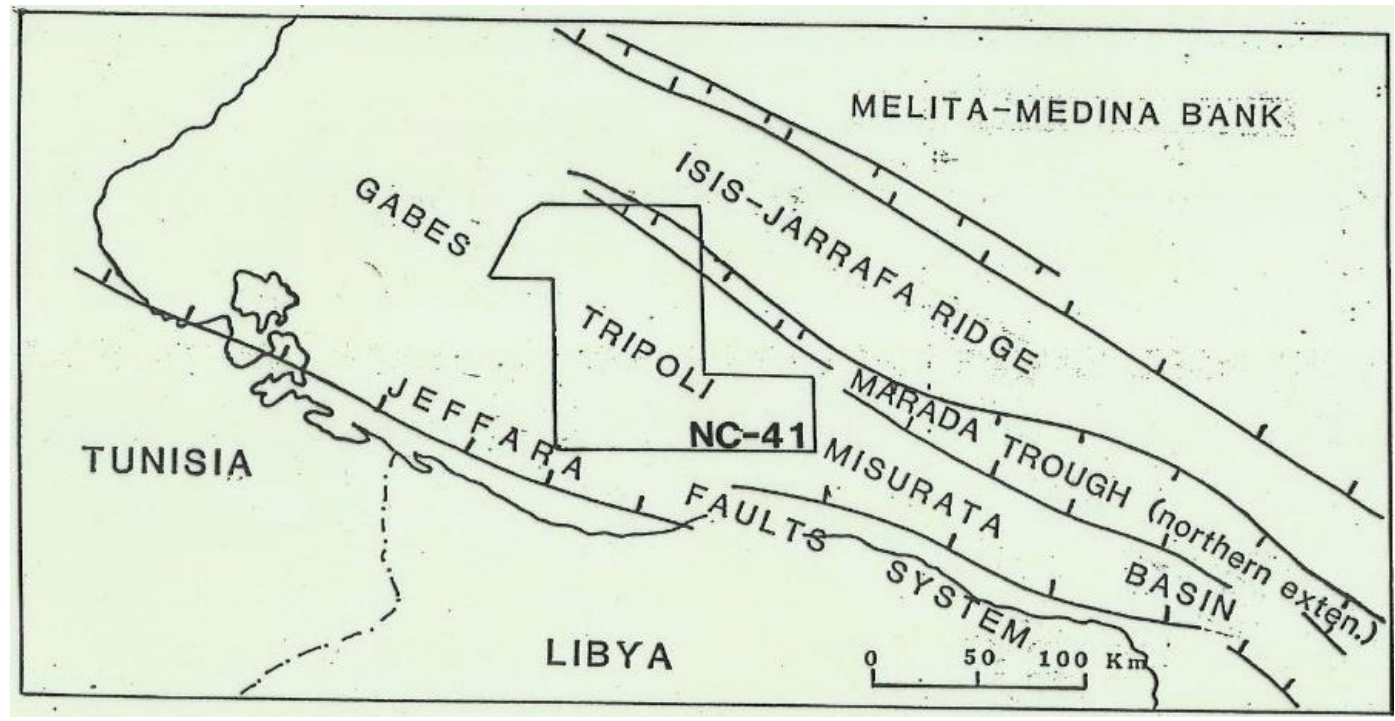

Figure (2): Schematic Tectonic Map, Modified After Breschl \& Gaith (1989), AGIP (NAME) Internal Report. 


\section{Rock Stratigraphic Units}

Rock stratigraphic units which have been penetrated by the studied wells, defined by lithological biostratigraphical and by correlation of electrical logs, are as follows: Metlaoui, El Haria, Abiod, Aleg, Douleb and Zebbag Formations, respectively.

\section{Metlaoui Formation}

This unit is Lower Eocene in age in the study area, and lithologically characterized by Limestone medium hard sometimes, grading to dolomitic limestone interbedding with shale, fossiliferous, Nummulites, Orbitolites and Alveolina. This unit has been penetrated by all study wells with variable thickness. The thickest one is marked in F1/NC41 well (1264 feet) while the thinnest one is marked in the $\mathrm{K} 1$ /NC41 well (82 feet).

\section{El Haria Formation}

This unit stratigraphically lies under the Metlaoui Formation, it is diachronous (PaleoceneMaastrichtian) and lithologically characterized by deep marine environment sediment; Argillaceous marl sometimes grading to marly limestone rich with pelagic fauna. This unit is divided into two members, "A" and "B", the "B" member is Paleocene in age, while the "A" member is Cretaceous. These two members of El Haria Formation are encountered only in the $\mathrm{F} 1$ /NC41well, conversely in the rest of the wells only " $\mathrm{A}$ " member is penetrated and in P1/NC41 well the two members are missing. The maximum thickness of these two members have been encountered in F1/NC41 well (1935 feet), where the minimum thickness is found in G1/NC41 well.

\section{Abiod Formation}

Abiod Formation is Early Maastrichtian- Campanian in age compose of chalky limestone sometimes grading to marly limestone, with pelagic planktonic fauna indicating deep marine environment (Keller, 1988). This stratigraphic reaches its maximum thickness in F1/NC41 well in the eastern side of the study area, and minimum thickness in N1, G1 and $\mathrm{K} 1 / \mathrm{NC} 41$ wells towards the west, however in $\mathrm{P} 1 / \mathrm{NC} 41$ it pinches out.

\section{Aleg Formation}

Aleg Formation is Turonian- Santonian in age and considered as deep marine sediment (Cococcettea, 1981), which mainly composed of shaly marl sometimes with marly limestone interbeds, with pelagic faunal assemblages, the above mentioned unit is distributed all over the study area except in P1 /NC41 well it is characterized by equivalent sallow marine facies Douleb Eq. Formation (Dolomitic Limestone). 


\section{Biostratigraphic Summary}

The deep marine sediment, El Haria Formation, is generally overlain by unconformably shallow marine sediment of Metlaoui Group and divided into unconformable members (A \& B) by $\mathrm{K} / \mathrm{T}$ boundary as indicated by biostratigraphic sequence affected by Late Cretaceous tectonic activity, which is evidentiated by the absence of the uppermost Maastrichtian zone (Abathomphalus mayaroensis). This is probably due to the fact that the Early Maastrichtian sediments emerged at that time, so it was impossible for the uppermost Maastrichtian sediments to be deposited.

Furthermore, toward the side of the study area (P1/NC41) well, sediments belonging to the Paleocene, Maastrichtian and Campanian times are completely absent. In such area the Lower Eocene directly overlies on the sediment of Santonian/Conacian (Doleb Eq. Formation). The Paleocene transgression continued over deep marine Maastrichtian sediment as shown in F1/NC41 well toward the east.

Widespread absence of uppermost Maastrichtian/Earliest Paleocene zonation all over the study area agrees with the hypothesis that attributed to this absence according to Late Cretaceous/ Early Paleocene mass extinction.

The Early Paleocene / Upper Cretaceous sediment sequence of five wells in the study area (F1, G1, N1, P1 and K1) have been microscopically analyzed which led to identification of the Early Paleocene/ Upper Cretaceous biostratigraphic zonal markers. This zonal markers definitions are based on Agip Zonations (Biozonation Microfossils, Agip 1985).

\section{Early Paleocene (Danian) (Globocousa Daubjergensis Sub-Zone)}

It is represented by the whitish grey calcareous shale sometimes grading to calcareous marl with abundant planktonic foraminiferal assemblages Postuma, (1971).

\section{Globoconusa Daubjergensis Sub-Zone}

Type: Interval Sub-Zone.

Definition: Interval from first occurrence of Globoconusa daubjergensis to first occurrence of Morrozovella trinidadensis.

This sub-zone is present only in the F1/NC41 well (range chart of F1/NC41 well \& Table (2)). The marker is associated with small Globigerinidae, Globorotalia trinidadensis, Globorotalia angulata, Globorotalia ehrenbergi, Neoflabllina and Haplophragimoides.

\section{Upper Cretaceous "Maastrichtian Campanian" (Globotruncana Stuarti Group)}

It is represented by slightly calcareous shale, fossiliferous, grading downward to argillaceous limestone. 


\section{Globotruncana Stuarti Group zone}

Type: Interval and Distribution Total Range Zone.

Definition: Interval from first occurrence of Dicarinella and first occurrence of Globotruncana Stuarti Group to last occurrence of Globotruncanidae, Hedbergella and Globigerinelloides (Bolli et al.,1985).

\section{Globotruncana Contuse Sub-Zone (Maastrichtian)}

Type: Interval Sub- Zone.

Definition: Interval from first occurrence of Globotruncana contuse to_first occurrence of Abathomphalus mayaroensis.

This sub-zone is only marked in the F1/NC41 well at 10620 feet associated with Pseudotextularia elgans, Racenigumbelina fructicusa, Hedbergella spp, Heterohelix striata, Globotruncanita suarti, Rugoglobigerina rugosa, Gyrodinoides spp, Haplophragmoides spp, Bolivinoides spp, Neoflabellina spp and Lenticulnae.

\section{Gansserina Gansseri Sub-Zone}

This sub-zone is only penetrated in the F1/NC41 well (range chart of F1/NC41 well \& Table (2)).

Type: Interval Sub-Zone.

Age: Maastrichtian.

Definition: Interval from first occurrence of Gansserina gansseri to the first occurrence of Globotruncana contuse.

This sub-zone characterized by the following thanatocoensis: Globotruncana stuatriforms, Globotruncana stuarti, Rugoglobigerina scotti, Rugoglobigerina rugosa, Pseudotextularia elgans, Racenigumbelina fructicusa, Globotruncana aegyptica, Heterohelix striata, Heterohelix subglobosa Bolminoides spp and Lenticulinae.

\section{Globotruncana Tricarinata Sub- Zone}

Type: Partial Range Sub-Zone.

Age: Maastrichtian.

Definition: Interval from last occurrence of Globotruncana calcarata to the first occurrence of Gansserina gansseri. 
This sub-zone is uneducable in the studied wells, but it does not mean not ore sent, because its equivalent sub-zone is present, such as Globotruncana aegyptica and Globotruncana havanensis that represent the lowermost part of Maastrichtian. The above mentioned sub-zone or its equivalent is missing only from N1/NC41 and P1/NC41 wells (Table 2).

\section{Globotruncana Calcarata Sub-Zone}

This sub-zone is missing from N1 and P1 wells (see range chart and Table (2)).

Type: Total Range Sub-Zone.

Definition: Interval from the first occurrence of Globotruncana calcarata to the last occurrence of Globotruncana calcarata.

This interval includes the uppermost part of Abiod sequence which is characterized by slightly argillaceous limestone with marl interbeds associated with faunal assemblages as follows: Globotruncana lapparenti, Globotruncana falsostuarti, Globotruncana bulloides, Gyrodinoides spp, Bolivinoides spp, Lenticulna spp and Globotruncanita conica.

\section{Globotruncana Stuartiformis Sub-Zone}

Type: Partial Range Sub-Zone.

Age: Campanian.

Definition: Interval from last occurrence of Marginotruncana to first occurrence of Globotruncana calcarata.

This sub-zone is present in P1 well Table (2). The thanatocoenosis assemblages of this subzone are: Golbotruncanita stuarti, Globotruncana ventricosa, Globotruncanella havanensis, Globotruncana Linneiana, Globotruncana arca, Rosita fornicate, Archeoglobigerina cretacea, globotruncana bulliodes, Rugoglobigerina subcircumnodifer, Bolivinoides spp, Gyrodinoides spp, Whitenella spp, Anomalinoides, Hedbergella spp, Abathophalus cretacea, Rugoglobigerina marcocephala, Rugoglobigerina hexacamerata, Neoflabellina rugosa.

\section{Globotruncanita Elevate Sub-Zone}

Type: Interval Sub-Zone.

Age: Campanian.

Definition: Interval from last occurrence of Dicarinella and first occurrence of Globotruncana stuarti group.

The faunal assemblages associated with this sub-zone are as follows: 
Globotruncana elevate, Globotruncana imbrecata, Globotruncana subspinosa, Rosita fornicate, Globotruncana lapparenti (Form of Archaeoglobigerina bosquensis= marker in the uppermost part of Santonian), Siderolites calcirapodes, Marginotruncana marginata, (Marginotruncana schneegansi $=$ uppermost part of Santonian), globotruncana bulliodes, Planoglobulina spp, Heterohelix, Gavwlinella spp Bolivinoides spp, Stensioina exculpate grasili Hedbergella spp and Globigerinelloides spp.

\section{Dicarinella Zone "Upper Turonian- Santonian"}

Type: Interval Zone.

Age: Upper Turonian- Santonian.

Definition: Interval from last occurrence of Helvetoglobotruncana helvetica to last occurrence of Dicarinella.

\section{Dicarinella Asymmetrica Sub-Zone}

Type: Distribution Range Zone.

Age: Upper Turonian to Upper Santonian.

Definition: Interval from first occurrence of Dicarinella asymmetrica to last occurrence of Dicarinella including Dicarinella asymmetrica and Marginotruncana sigali.

The faunal assemblages associated with this sub-zone are as follows: Dicarinella asymmetrica, Whitenella inornata, Whitenella baltica, Marginotruncana coronate.

Globotruncanita subspinosa, Dicarinella concavata, Dicarinella canaliculata, Marginotruncana schneegansi, Ammodiscus cdetaceous, Heterohilicidae Anomalinoidae, Dorothia.

\section{Dicarinella Concavata Sub-Zone}

Type: Partial Distribution Sub-Zone.

Age: Santonian.

Definition: Interval from last occurrence of Dicarinella primitive, Marginotruncana sigali, Whitenella and first occurrence of Globotruncana sigalia to first occurrence Dicarinella asymmetrica.

The faunal assemblages associated with this sub-zone are as follows:

Dicarinella concavata, Whitenella inornata, Whitenella paradubia, Marginotruncana pseudolinneiana, Marginotruncana concavata, Rosita fornicate 1.o., Marginotruncana marginata, Dicarinella canaliculata, Hedbergella spp, Heteroeholicidae, Gavelinella spp, 
Archaeoglobgerina cretacea, Dicarinella imbrecata, Dicarinella primitive, Marginotruncana renzi.

Note: the above planktonic foraminiferal sub-zone is detected in the whole studied wells except P1/NC41 which is un-zonable Table (2) and annex (1).

\section{Dicarinella Primitiva Sub-Zone}

Type: Total Distribution Range Sub-Zone.

Age: Conacian.

Definition: Interval from first occurrence of Dicarinella primitive to last occurrence of Dicarinella primitive, Marginotruncana sigali and Whitenella.

This thanatocoensis assemblages of this sub-zone are: Dicarinella concavata, Dicarinella primitive, Dicarinella imbrecata, Dicarinella canaliculata, Marginotruncana marginata, Hedbergella spp, Hedbergella flandrini, Hedbergella simplex, Hedbergella delrioensis, Whitenella baltica, Whitenella paradubia, Globigerinoides ultramicra.

This sub-zone is penetrated in the study wells with variable thickness, except the P1/NC41 well which has not been zonable annex (1).

\section{Marginotruncana Sigali Sub-Zone}

Type: Partial Distribution Sub-Zone.

Age: Turonian.

Definition: Interval from last occurrence of Helvetoglobotruncana Helvetica to first occurrence Dicarinella primitive.

The faunal assemblages of this sub-zone are: Marginotruncana sigali,

to occurrence of Dicarinella primitive, and first Whitenella, Dicarinella imbrecata, Whitenella baltica, Whitenella paradubia, Globigerinoides spp, Marginotruncana marianosi, Marginotruncana renzi, Marginotruncana schneegansi, Marginotruncana coronate, Hedbergella spp, Dicarinella hangi, Praeglobotruncana stephni, Hedbergella flandrini.

Note: This sub-zone is dectectable in all studied wells except P1 /NC41 well. This was probably due to the fact that there was no deposition or it has eroded away (as shown in range chart \& Table (2)).

\section{Helvetoglobotruncana Helvetica Zone}

Type: Interval Zone. 
Age: Turonian.

Definition: Interval from last occurrence of Rotalipora to last occurrence of Helvetoglobotruncana Helvetica.

The associated assemblages of this zone are: Helvetoglobotruncana Helvetica, Marginotruncana renzi, Marginotruncana schneegansi, Marginotruncana sigali, Praeglobotruncana stephn, Heterohelix moremani, Hedbergella delvioensis, Globigerinoidae, Rotalipora cushmani, Gavelinella spp, Anomalinoidae, Lenticulina.

\section{Rotalipora Zone}

Type: Interval Zone.

Age: Cenomanian.

Definition: Interval from last occurrence of Planomalina buxturfi to last occurrence of Rotalipora.

Note: only the upper part of this zone is penetrated in the study area.

\section{Rotalipora Cushmani Sub-Zone}

Type: Interval-Sub Zone.

Age: Upper Cenomanian.

Definition: Interval from last occurrence of Thlmanninella appenninica to last of occurrence of Rotalipora.

The faunal assemblages of this sub-zone are: Rotalipora Cushmani, Rotalipora greenhornensis, Rotalipora spp, Praeglobotruncana stephni, Hedbergella simplex, Hedbergella delrioensis, Hedbergella planispira, Gavelinella spp, Anomalinoidae, Stensiona exculpate graclis, Whitenella paradubia.

This sub-zone is noted in the whole study area except in the P1/NC41 well Table (2) \& range charts.

\section{Thlmanninella Appenninica Sub-Zone}

Type: Interval-Sub Zone.

Age: Early Cenomanian.

Definition: Interval from last occurrence of Planomalina buxtorfi to last occurrence of Thlmanninella reicheli. 
The association assemblages of this sub-zone are: Thlmanninella appenninica, Thlmanninella brotzeni, Thlmanninella reicheli, Rotalipora gandolfi, Hedbergella delrioensis, Favusella washitensis, praglobotrucana stephani, Ticinella roberti, Hedbergella planispira, hedbergella simplex, Dentalina terquemi, Anomalinoidae, Planoglobulina glabarta, gavelinopsis cenomanica, Dorthia gradate.

Note: This sub-zone is marked in N1,G1and K1 NC/41 wells and unmarked in wells F1and P1 because either this sub-zone is still below the TD, especially in well F1 or it is missing due to erosion and/or non-deposited, as probably in P1/NC41 (see Table (2), range chart of F1 well \& annex (1)). 


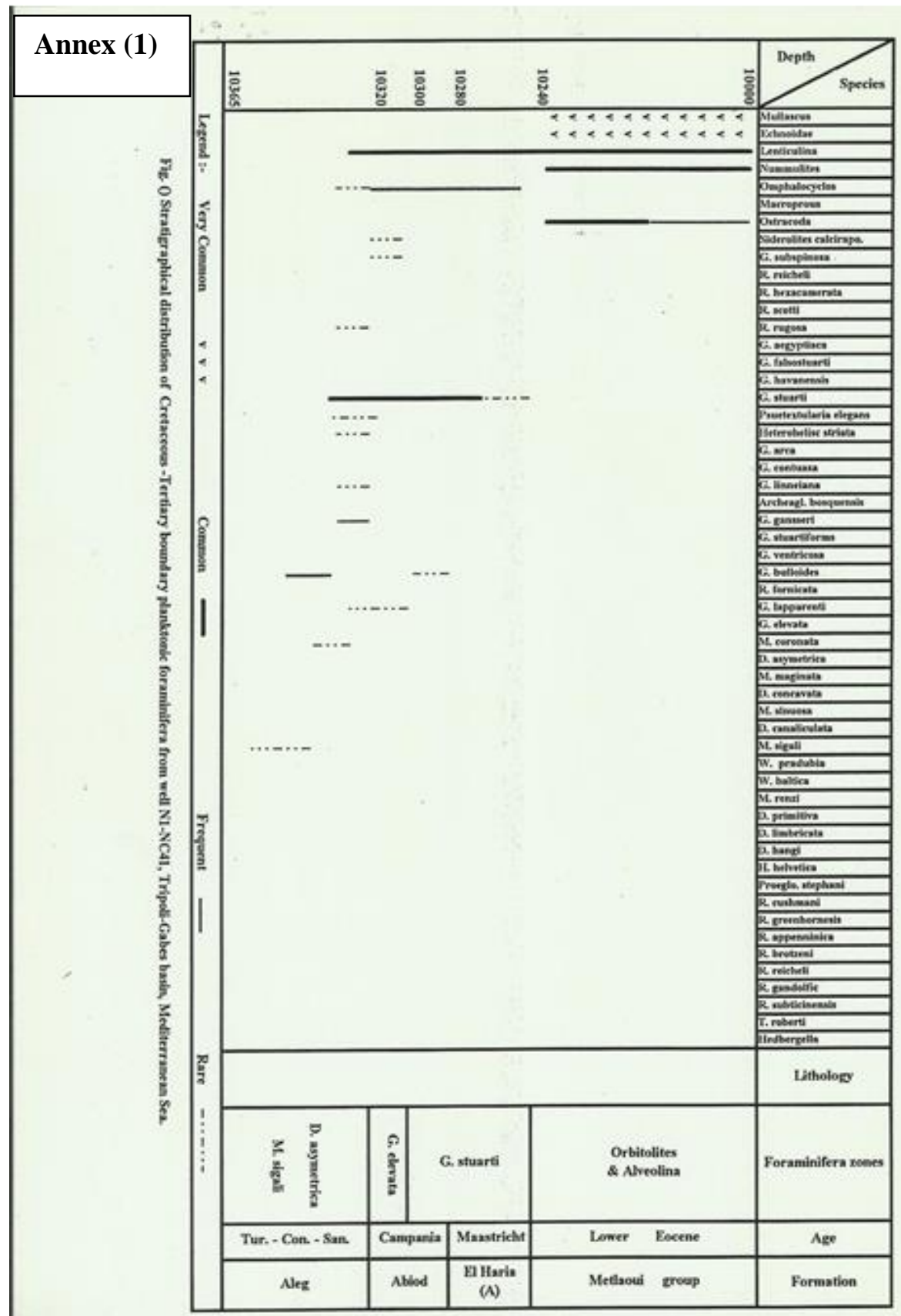




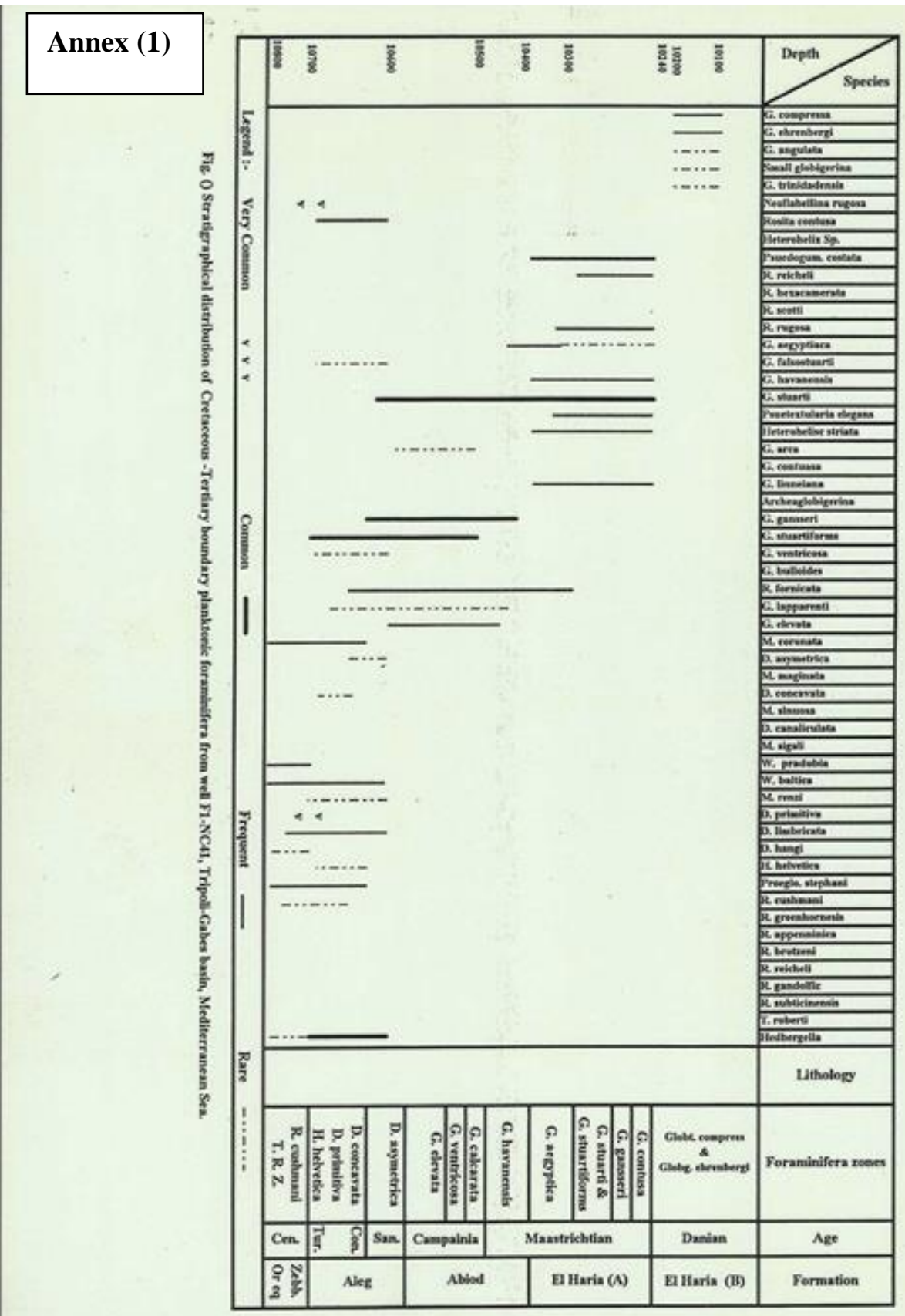




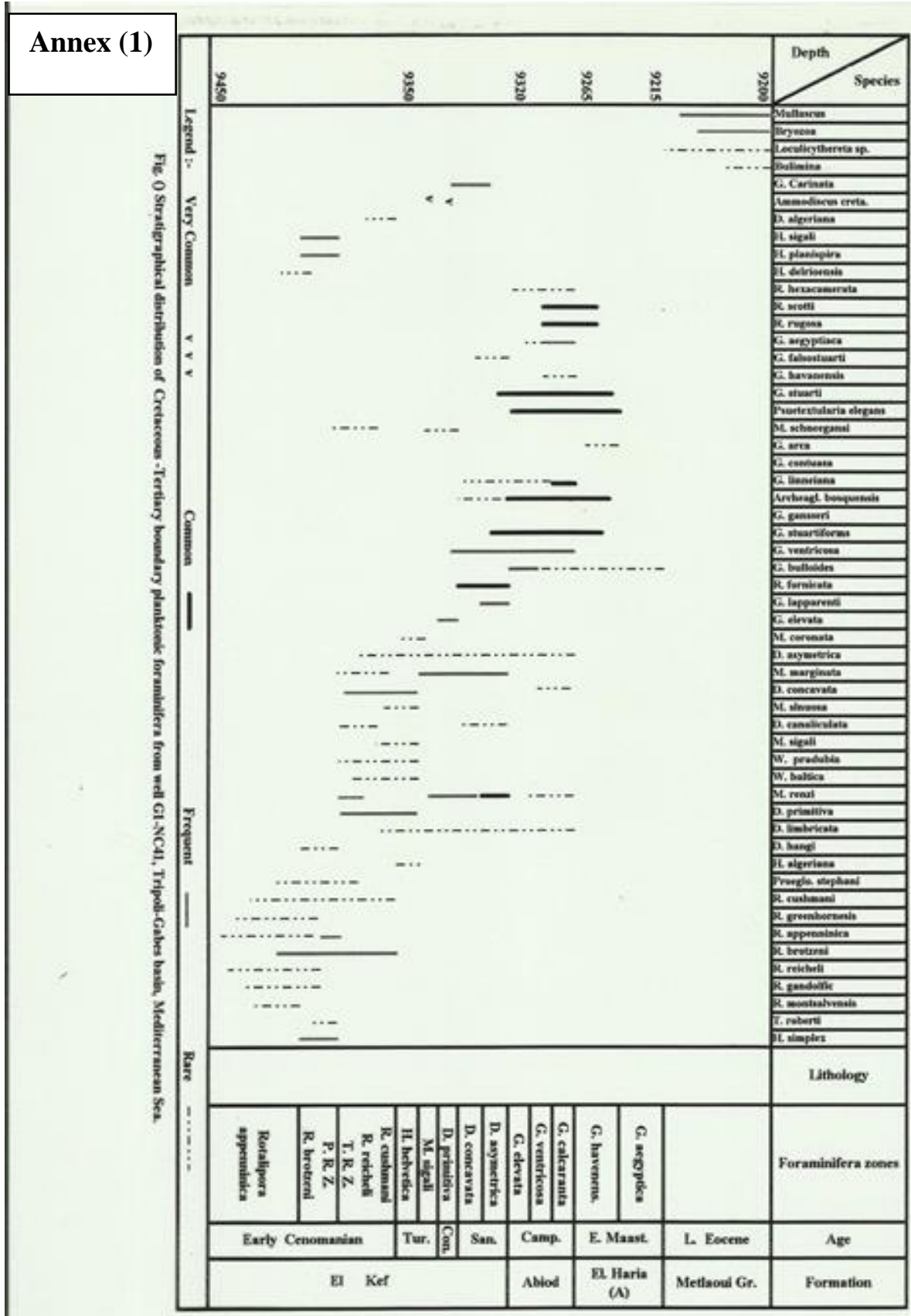




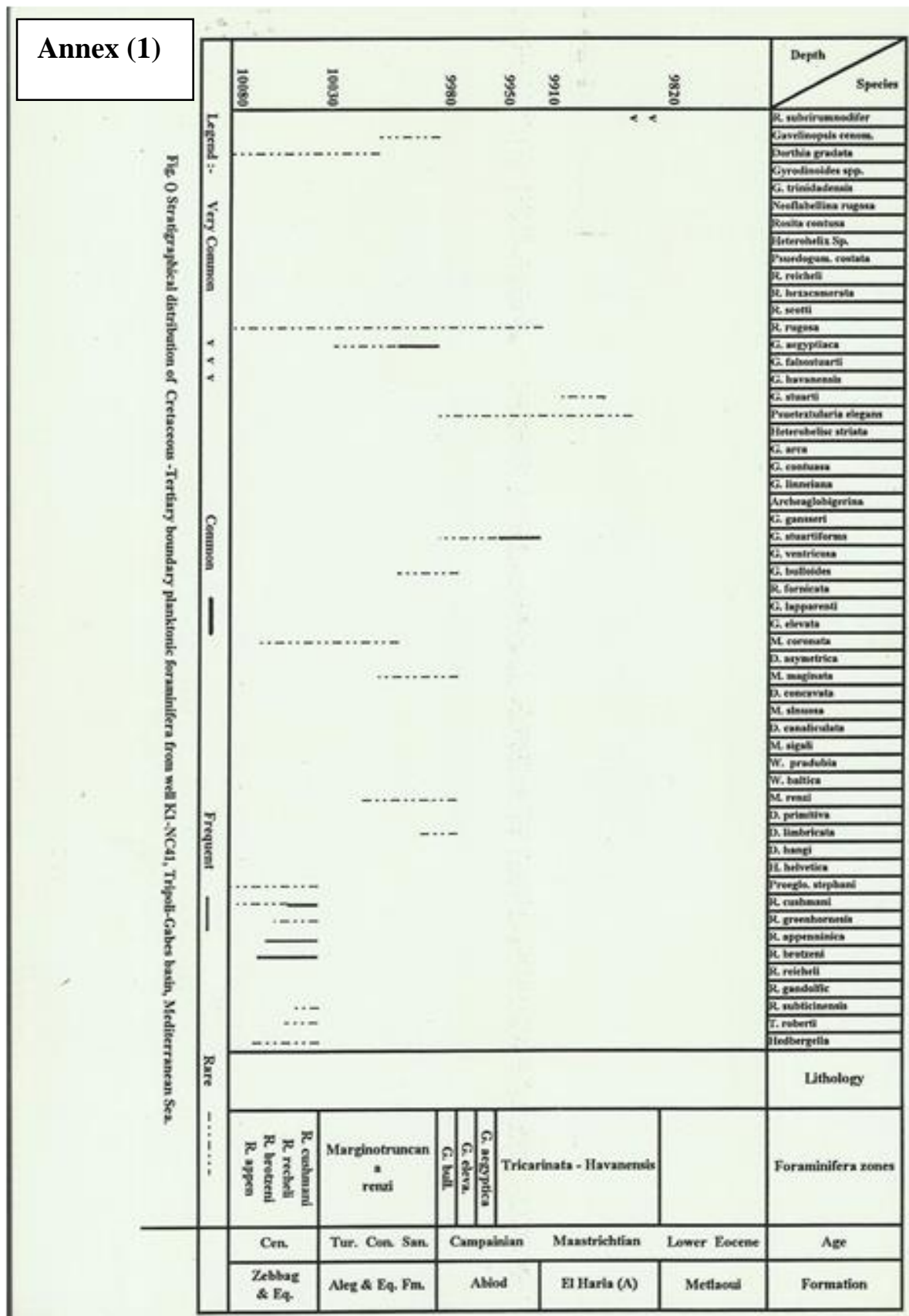


Table (1): Planktonic Foraminifral Zonal Scheme and Datum Markers Used in This Study.

\begin{tabular}{|c|c|c|c|}
\hline \multicolumn{2}{|c|}{ 岁 } & \multicolumn{2}{|c|}{$\begin{array}{l}\text { PLANKTONIC. } \\
\text { RMIMFERAL ZQNES }\end{array}$} \\
\hline 品 & 崖 & \multicolumn{2}{|c|}{$\begin{array}{l}\text { ALVEOLINAE } \\
\text { NUMMULITE } \& \\
\text { ORBITOLITES }\end{array}$} \\
\hline \multicolumn{2}{|c|}{ L. PALED } & \multicolumn{2}{|c|}{$\begin{array}{c}\text { S. PSUED. G. DAUBJERGENSIS } \\
\text { A. MAYAR }\end{array}$} \\
\hline \multirow{4}{*}{ 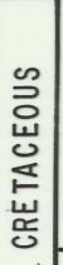 } & \multirow{3}{*}{ 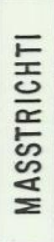 } & \multirow{6}{*}{ 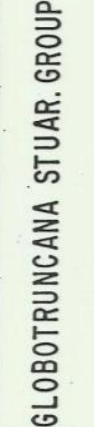 } & \begin{tabular}{|l} 
A. MAYAR \\
G.
\end{tabular} \\
\hline & & & G. GANSSERI \\
\hline & & & TRICARINATA \\
\hline & \multirow{3}{*}{ 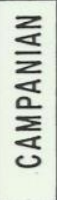 } & & G. CALCARATA \\
\hline & & & $\begin{array}{l}\text { G. STUARTIF- } \\
\text { ORMIS }\end{array}$ \\
\hline & & & G. ELEVATA \\
\hline
\end{tabular}

DATUM MARKERS

MORROZVELLA TRINIDADENSIS

F. GLOROCONOUSA DAUBJERGENSIS

L. GLOBOTRUNCANIDAE, H.d. Q G GLOBIGE RN ELLOIDES

F. A. MAYAROENSIS.

F. G. CONTOUSA

F. G. GANSSERI

L.G. CALCARATA

F. G. CALCARATA

L. MARGINOTRUNCANA

L. DICARINELLA \& F G, STUARTI GROUP

TABLE:1 PLANKTONIC FORAMINIFRAL ZONAL SCHEME AND DATUM MARKERS USED IN THIS STUDY

F : FIRST OCCURENCE \& L: LAST OCCURENCE 
Table (2): Correlation of Study Area Zone with Agip 1985 Standard Zonation Scheme.

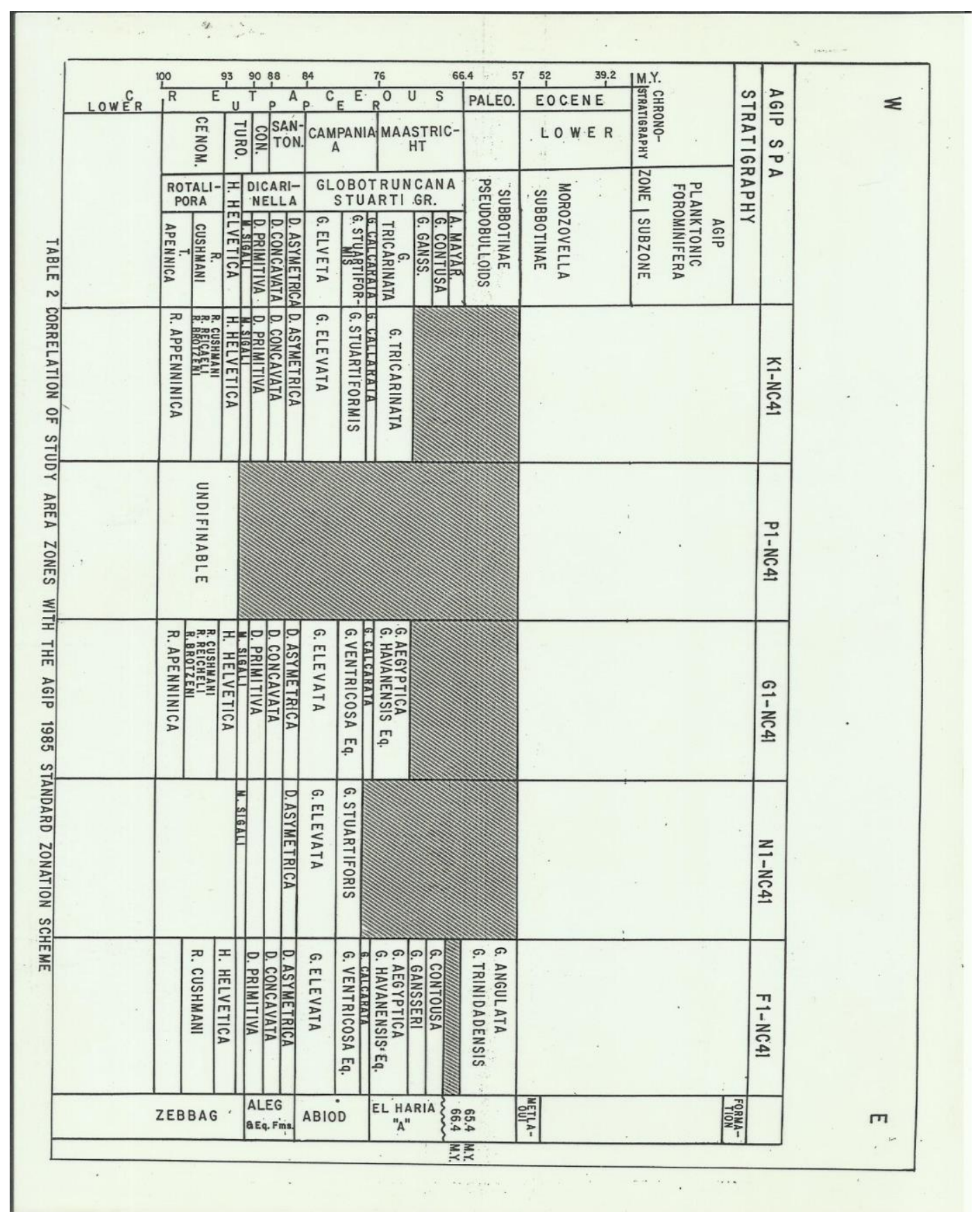

\section{Conclusion}

- Duration of the Cretaceous / Tertiary Unconformity varies from minimum in F1 well area to a maximum in P1 well area.

- 15 sub-zones missing in the P1 well equivalent about 30 my. 
- 2 sub-zones missing in the $\mathrm{F} 1$ equivalent to about $2 \mathrm{my}$.

- The Abiod formation, a producing reservoir in Tunisian offshore, attains its maximum thickness in F1 well area.

- Continuous coring of the Early Paleocene/Upper Cretaceous sediment is recommended in order to clarify the biostratigraphic zonation encountered in Concession NC41. This should also be carried out to be certain of the sequence of sediment beyond the Abiod Formation completely attributed to it or to the older units.

\section{References}

- Agip SPA. 1985. Biozonatura a Microfossili dal Triassico al Quaternario in area Mediterranea. Internal report, pp1-56.

- Anketell,J.M. and Ghellali,S.M.(1991b). Quaternary sediments of the Jifarah plain, In: The Geology of Libya,(eds Salem,M.J.and Belaid, M.N.), Academic.

- Bolli, H.M., Saunders, J. B., Perch-Nielsen, K (eds). 1985 Cretaceous planktonic foraminifera. Cambridge University Press pp 17-86.

- Berschi, A, et al 1989. Geological study of Mesozoic-Tertiary Sequences in the Tripoli //Gabes Basin and links with the Malta/ Ragusa platform. Agip NAME, Internal report, pp1-72.

- Cococcettea, V. 1981. NC41 area stratigraphic \& Facies, Agip NAME, Internal report, pp1-72.

- Douglas, R. G., 1972. Paleozoogeography of Late Cretaceous planktonic Foraminifera in North America. Journal of Foraminiferal Research, 2: 14-34.

- Keller, G. 1988. Extinction survivorship and evolution of planktonic foraminifera across the Cretaceous/ Tertiary boundary at El Kef, Tunisia. Marine Micropaleontology, 13, pp239-263.

- Lazzari, G,1990, Genesis of the salt domes and walls in the Tripoli-Gabes Basin - offshore Libya.AGIP (NAME), internal report, pp. 12.

- Postuma, J. (1971) Manual of Planktonic Foraminifera. Elsevier Publishing Co., Amsterdam, 420. Lazzari, 1990). 